\title{
The burglar of Babylon
}

\author{
ELIZABETH BISHOP
}

On the fair green hills of Rio

There grows a fearful stain:

The poor who come to Rio

And can't go home again.

On the hills a million people, A million sparrows, nest, Like a confused migration That's had to light and rest,

Building its nests, or houses, Out of nothing at all, or air. You'd think a breath would end them, They perch so lightly there.

But they cling and spread like lichen, And the people come and come.

There's one hill called the Chicken, And one called Catacomb;

There's the hill of Kerosene, And the bill of the Skeleton, The bill of Astonishment, And the hill of Babylon.

Micuçü was a burglar and killer, An enemy of society.

He had escaped three times

From the worst penitentiary.

They don't know how many he murdered (Though they say be never raped), And be wounded two policemen This last time he escaped.

They said, "He'll go to his auntie, Who raised him like a son.

She has a little drink shop

On the bill of Babylon".

* Nota da autora: Micuçu (mẽ - coo - soo) is the folk name of a deadly snake, in the North. 


\section{O ladrão da Babilônia}

Tradução de Paulo Henriques Britto

Nos morros verdes do Rio

Há uma mancha a se espalhar:

São os pobres que vêm pro Rio

E não têm como voltar.

São milhares, são milhões,

São aves de arribação,

Que constróem ninhos frágeis

De madeira e papelão.

Parecem tão leves que um sopro

Os faria desabar

Porém grudam feito líquens

Sempre a se multiplicar,

Pois cada vez vem mais gente.

Tem o morro da Macumba, Tem o morro da Galinha,

E o morro da Catacumba;

Tem o morro do Querosene, O Esqueleto, o do Noronha, Tem o morro do Pasmado E o morro da Babilônia.

Micuçú * era ladrão, Assassino, salafrário. Tinha fugido três vezes Da pior penitenciária.

Dizem que nunca estuprava, Mas matou uns quatro ou mais. Da última vez que escapou Feriu dois policiais.

Disseram: "Ele vai atrás da tia, Que criou o sem-vergonha.

Ela tem uma birosca

No morro da Babilônia”.

* Nota da autora: nome popular de uma cobra da região Norte cujo veneno é mortal. 
He did go straight to his auntie, And he drank a final beer.

He told her, "The soldiers are coming, And I've got to disappear.

"Ninety years they gave me.

Who wants to live that long?

I'll settle for ninety hours,

On the hill of Babylon.

"Don't tell anyone you saw me.

I'll run as long as I can.

You were good to me, and I love you, But I'm a doomed man.”

Going out, he met a mulata Carrying water on her head.

"If you say you saw me, daughter,

rou're just as good as dead."

There are caves up there, and hideouts, And an old fort, falling down. They used to watch for Frenchmen From the hill of Babylon.

Below him was the ocean. It reached far up the sky, Flat as a wall, and on it Were freighters passing by,

Or climbing the wall, and climbing Till each looked like a fly, And then fell over and vanished; And he knew he was going to die.

He could hear the goats baa-baa-ing, He could hear the babies cry; Fluttering kites strained upward; And he knew he was going to die.

A buzzard flapped so near him He could see its naked neck. He waved his arms and shouted, "Not yet, my son, not yet!" 
E foi mesmo lá na tia,

Beber e se despedir:

"Eu tenho que me mandar,

Os home tão vindo aí.

Eu peguei noventa anos,

Nem quero viver tudo isso!

Só quero noventa minutos,

Uma cerveja e um chouriço.

"Brigado por tudo, tia,

A senhora foi muito legal.

Vou tentar fugir dos home,

Mas sei que eu vou me dar mal".

Encontrou uma mulata

Logo na primeira esquina.

"Se tu contar que me viu

Tu vai morrer, viu, menina?"

Lá no alto tem caverna,

Tem esconderijo bom,

Tem um forte abandonado

Do tempo de Villegaignon.

Micuçú olhava o mar

E o céu, liso como um muro.

Viu um navio se afastando,

Virando um pontinho escuro,

Uma mosca na parede,

Até desaparecer

Por detrás do horizonte.

E pensou: "Eu vou morrer".

Ouvia berro de cabra,

Ouvia choro de bebê,

Via pipa rabeando,

E pensava: "Eu vou morrer".

Urubu voou bem baixo,

Micuçú gritou: "Péra aí",

Acenando com o braço,

"Que eu ainda não morri!" 
An Army belicopter

Came nosing around and in.

He could see two men inside it,

But they never spotted him.

The soldiers were all over,

On all sides of the bill,

And right against the skyline

A row of them, small and still.

Children peeked out of windows,

And men in the drink shop swore,

And spat a little cachaça

At the light cracks in the floor.

But the soldiers were nervous, even

With tommy guns in hand,

And one of them, in a panic,

Shot the officer in command.

He hit him in three places;

The other shots went wild.

The soldier had hysterics

And sobbed like a little child.

The dying man said, "Finish

The job we came here for".

He committed his soul to God

And his sons to the Governor.

They ran and got a priest, And he died in hope of Heaven - A man from Pernambuco, The youngest of eleven.

They wanted to stop the search, But the Army said. "No, go on", So the soldiers swarmed again Up the hill of Babylon.

Rich people in apartments Watched through binoculars As long as the daylight lasted. And all night, under the stars, 
Veio helicóptero do Exército

Bem atrás do urubu.

Lá dentro ele viu dois homens

Que não viram Micuçú.

Logo depois começou

Uma barulheira medonha.

Eram os soldados subindo

O morro da Babilônia

Das janelas dos barracos, As crianças espiavam.

Nas biroscas, os fregueses

Bebiam pinga e xingavam.

Mas os soldados tinham medo

Do terrível meliante.

Um deles, num acesso de pânico, Metralhou o comandante.

Três dos tiras acertaram

Os outros tiraram fino.

O soldado ficou histérico:

Chorava feito um menino.

O oficial deu suas ordens, Virou pro lado, suspirou, Entregou a alma a Deus

E os filhos ao governador.

Buscaram depressa um padre, Que lhe deu a extrema-unção.

- Ele era de Pernambuco,

$\mathrm{O}$ mais moço de onze irmãos.

Queriam parar a busca,

Mas o Exército não quis.

$\mathrm{E}$ os soldados continuaram

A procurar o infeliz.

Os ricos, nos apartamentos, Sem a menor cerimônia, Apontavam seus binóculos Pro morro da Babilônia. 
Micuçu hid in the grasses

Or sat in a little tree,

Listening for sounds, and staring

At the lighthouse out at sea.

And the lighthouse stared back at him, Till finally it was dawn.

He was soaked with dew, and hungry,

On the bill of Babylon.

The yellow sun was ugly,

Like a raw egg on a plate-

Slick from the sea. He cursed it,

For be knew it sealed his fate.

He saw the long white beaches

And people going to swim,

With towels and beach umbrellas,

But the soldiers were after him.

Far, far below, the people

Were little colored spots,

And the heads of those in swimming

Were floating coconuts.

He heard the peanut vendor

Go peep-peep on his whistle,

And the man that sells umbrellas

Swinging his watchman's rattle.

Women with market baskets

Stood on the corners and talked,

Then went on their way to market,

Gazing up as they walked.

The rich with their binoculars

Were back again, and many

Were standing on the rooftops,

Among TV antennae.

It was early, eight or eight-thirty.

He saw a soldier climb,

Looking right at him. He fired, And missed for the last time. 
Depois, à noite no mato, Micuçú ficou de vigília, De ouvido atento, olhando

Pro farol lá longe, na ilha,

Que olhava pra ele também,

Depois dessa noite de insônia Estava com frio e com fome, No morro da Babilônia.

O sol nasceu amarelo, Feio feito um ovo cru. Aquele sol desgraçado Era o fim de Micuçú.

Ele via as praias brancas, Os banhistas bem dormidos, Com barracas e toalhas. Mas ele era um foragido.

A praia era um formigueiro: Toda a areia fervilhava, E as pessoas dentro d'água Eram cocos que boiavam.

Micuçú ouviu o pregão Do vendedor de barraca, E o homem do amendoim Rodando sua matraca.

Mulheres que iam à feira Paravam um pouco na esquina Pra conversar com as vizinhas, $\mathrm{E}$ às vezes olhavam pra cima.

Os ricos, com seus binóculos, Voltaram às janelas abertas. Uns subiam nos telhados Para assistir mais de perto.

Um soldado - ainda era cedo, Oito horas, oito e dez Fez mira no Micuçú E errou pela última vez. 
He could hear the soldier panting,

Though he never got very near.

Micuçu dashed for shelter.

But he got it, behind the ear.

He heard the babies crying

Far, far away in his head,

And the mongrels barking and barking.

Then Micuçu was dead.

He had a Taurus revolver,

And just the clothes he had on,

With two contos in the pockets,

On the bill of Babylon.

The police and the populace

Heaved a sigh of relief,

But behind the counter his auntie

Wiped her eyes in grief.

"We have always been respected.

My shop is honest and clean.

I loved him, but from a baby

Micuçú was always mean.

"We bave always been respected.

His sister has a job.

Both of us gave him money.

Why did he have to rob?

"I raised him to be honest,

Even here, in Babylon slum".

The customers had another,

Looking serious and glum.

But one of them said to another,

When he got outside the door,

"He wasn't much of a burglar,

He got caught six times - or more".

This morning the little soldiers

Are on Babylon hill again;

Their gun barrels and helmets

Shine in a gentle rain. 
Micuçú ouvia o soldado

Ofegando, esbaforido,

Tentou se embrenhar no mato:

Levou uma bala no ouvido.

Ouviu um bebê chorando

E sua vista escureceu.

Um vira-lata latiu.

Então Micuçú morreu.

Tinha um revólver Taurus

E mais as roupas do corpo,

Com dois contos no bolso.

Foi tudo que acharam com o morto.

A polícia e a população

Respiraram aliviadas.

Porém na birosca a tia

Chorava desesperada.

"Eu criei ele direito,

Com carinho, com amor.

Mas não sei, desde pequeno

Micuçú nunca prestou.

"Eu e a irmã dava dinheiro, Nunca faltou nada, não.

Por que foi que esse menino

Cismou de virar ladrão?

"Eu criei ele direito,

Mesmo aqui, nessa favela".

No balcão os homens bebiam,

Sérios, sem olhar pra ela.

Mas já fora da birosca

Comentou um dos fregueses:

"Ele era um ladrão de merda.

Foi pego mais de seis vezes".

Hoje está chovendo fino

E estão de volta os soldados,

Com fuzis metralhadoras

E capacetes molhados. 
Micuçu is buried already. They're after another two, But they say they aren't dangerous As the poor Micuçu.

On the fair green hills of Rio There grows a fearful stain: The poor who come to Rio And can't go home again.

There's the hill of Kerosene, And the bill of the Skeleton, The bill of Astonishment, And the hill of Babylon. 
Vieram dar mais uma batida, Só que é outro criminoso.

Mas o pobre Micuçú -

Dizem - era mais perigoso.

Nos morros verdes do Rio Há uma mancha a se espalhar: São os pobres que vêm pro Rio $\mathrm{E}$ não têm como voltar.

Tem o morro do Querosene, O Esqueleto, o do Noronha, Tem o morro do Pasmado E o morro da Babilônia. 